DOI 10.36074/30.10.2020.v1.26

\title{
АНАЛІЗ МЕТОДІВ РОЗРАХУНКУ ТРИВАЛОСТІ ЗАДАЧ В УПРАВЛІННІ ПРОЕКТАМИ
}

Катаєва Євгенія Юріївна
канд. техн. наук, доцент кафедри програмного забезпечення автоматизованих систем Черкаський державний технологічний університет

Люта Майя В'ячеславівна ст. викладач кафедри інформаційно-комп'ютерних технологій та

фундаментальних дисциплін Київський національний університет технологій та дизайну

Овчаров Олександр Миколайович магістр кафедри кафедри інформаційно-комп'ютерних технологій та

фундаментальних дисциплін Київський національний університет технологій та дизайну

УКРАÏHA

В результаті комплексних економічних перетворень, які відбуваються в Україні, впроваджуються існуючі моделі та механізми побудови сучасних економічних відносин як у державі, так і на підприємстві. Відповідно, будь-який підприємець розуміє, що для подальшої прибуткової діяльності, насамперед, необхідно досконало управляти виробничо-господарською діяльністю. Важливе місце при цьому належить проектному управлінню.

Сьогодні ефективне управління проектами неможливе без використання сучасних програмних засобів, оскільки зростають розміри проектів, частота їх виконання, обсяги інформації.

В даний час найбільш популярними є кілька систем управління проектами: Microsoft Office Project (корпорація Microsoft), Spider Project Professional (розробник російська компанія "Технології управління Спайдер"), Primavera Project Planner (компанія Primavera Inc.), SureTrack Project Manager, Open Plan (розробник Welcom Software Technology, зараз Deltek) та багато інших систем.

Кожна програма має як ряд переваг, так і численні недоліки. Одним із вагомих фракторів, який спонукає замовляти розробку подібних програм, а не використовувати вже існуючі, $\epsilon$ авторське право. Кожен розробник хоче отримати за свій програмний продукт певні економічні блага, але дуже часто ціна за програму є не прийнятною для користувача. Також суттєвим недоліком $\epsilon$ те, що в існуючих програмних аналогах не використовуються математичні методи для розрахунку тривалості задач проекту.

Розглянемо де кілька методів розрахунку тривалості задач в проектах. В управлінні проектами широко використовується сітьове планування $[1,2$, 3]. Сітьовий графрік проекту розпоряджує операції у відповідній послідовності для розрахунку часу початку і закінчення операції. Для більш ефективного календарного планування використовується сітьовий графрік 3 відображеннями раннього старту, раннього фінішу, пізнього початку, пізнього закінчення, резерву часу, а також тривалості роботи.

Оцінка тривалості операції проводиться на основі витрат часу, необхідного для вирішення всіх задач, що складають набір робіт операції. 
Також $є$ можливістт використовувати PERT-моделювання в управління графріком проекту

Розподіл ресурсів за проектами (етапам проектів) у багатьох випадках призводить до зміни тривалості проектів, як на рівні очікуваних величин, так і параметрів розподілу.

Метод PERT [3, 4, 5], розроблений в середині 20-ого століття, став першою спробою розгляду невизначеності в розрахунках проектного графріку, i враховував в собі невизначеність тривалості робіт. Техніка пропонувала оцінку розподілу ймовірностей загальної тривалості проекту (етапів проекту). На основі отриманих оцінок можна прогнозувати терміни завершення етапів проекту 3 бажаною ймовірністю.

Моделі, побудовані на основі методології PERT, дозволяють враховувати технологічну невизначеність виконання основних операцій етапів інноваційних проектів, паралельність і логічний взаємозв'язок виконання комплексу операцій. В основі методології PERT лежать принципи та інструменти побудови стохастичних мережних моделей і метод статистичних випробувань МонтеКарло [5].

Розглянемо використання теорії нечітких множин в управлінні графріком проекту. Проблема управління проектами відноситься до завдань оптимізації в умовах невизначеності. Як правило, для вирішення подібних завдань залучається апарат теорії імовірності. Проте в ряді ситуацій, застосування теорії ймовірностей представляється недостатньо коректним і обгрунтованим. Причиною цьому $є$ недолік наявних даних, що не дозволяє з достатнім ступенем упевненості встановити адекватність обраної для опису ситуації ймовірнісної моделі. В таких умовах з'являється потреба в інших, відмінних від імовірнісного, підходах до оцінки наявної невизначеності. Один з таких підходів заснований на застосуванні теорії нечітких множин. Стосовно до проблеми управління проектами із залученням теорії нечітких множин стикаються 3 двома завданнями: отримання оцінок показників проекту у вигляді нечітких чисел, формування оптимального розподілу ресурсів проекту на основі отриманих нечітких оцінок. При управлінні проектами найбільш часто застосовується метод критичного шляху $[4,6,7,8,9]$, що дозволяє знайти максимальну тривалість проекту. Застосовується даний метод у випадку, коли є повна і точна інформація про тривалість операцій.

В даний час при управлінні проектами менеджери зіштовхуються 3 проблемою розмитості вихідних даних проекту. Особливо це відноситься до проектів, які розробляються і впроваджуються вперше і не мають яких-небудь статистичних даних. Огляд існуючих методів показав, що багато з них не адаптовані до використання нечітких оцінок, тому актуальним є застосування нечіткої логіки в управлінні проектами. Але при використанні гнучких методологій управління проектами, при поверхневому аналізі проекту бажано використовувати PERT аналіз проекту, для того щоб замовник зміг оцінити вартість проекту.

\section{Список використаних джерел:}

[1] Афанасьев, М.Ю. \& Суворов, Б.П. (2003) Исследование операций в экономике: модели, задачи, решения Афанасьев М.Ю. (ред). М.: ИНФРА-М

[2] Кудрявцев, Е.М. (2005) Методы сетевого планирования и управления проектом (ред) М.: ДМК Пресс.

[3] Хемди, А. Таха (2005) Введение в исследование операций (пер. с англ.) М.: Издательский дом «Вильямс» 
86 - Tendances scientifiques de la recherche fondamentale et appliquée • Volume 1

[4] Critical Path Analysis and PERT Charts). Вилучено із http://www.mindtools.com/critpath.html

[5] PERT. Вилучено із http://www.netmba.com/operations/project/pert/

[6] Samuel L. Baker Critical Path Method (CPM). Вилучено із http://hadm.sph.sc.edu/ courses/j716/cpm/cpm.html

[7] Critical Path Method). Вилучено із http://syque.com/quality_tools/tools/TOOLS16.htm

[8] Jesse Santiago, Desirae Magallon Critical Path. Вилучено із http://www.stanford.edu/ class/cee320/CEE320B/CPM.pdf

[9] Афранасьев, М. Ю., Багриновский, К.А.\& Матюшок, В.М. (2006) Прикладные задачи исследования операций Афранасьев М.Ю. (ред). М.: ИНФРА-М 